\title{
RELAKSASI TERAPI OTOT PROGRESIF TERHADAP PENURUNAN SKALA NYERI LOW BACK PAIN (LBP) PADA PENGRAJIN KESET
}

\author{
Eli Muflihah ${ }^{1}$, Rina Puspita Sari ${ }^{2}$ \\ 1,2 Prodi Ilmu Keperawatan STIKes Yatsi, Tangerang \\ Jl. Aria Santika No. 40A, RT 005/RW011 Margasari, Kec. Karawaci, Kota Tangerang, \\ Banten, Indonesia \\ $\underline{\text { eli3007215@gmail.com }}$
}

\begin{abstract}
Abstrak
Low Back Pain (LBP) atau nyeri punggung bawah adalah salah satu keluhan MSDs (Muskuloskeletal Disordes) yang sering dikeluhkan oleh para penjahit. Di negara-negara industri, sekitar 80 persen penduduknya pernah mengalami LBP yang sering terjadi pada umur 35 sampai 55 tahun. Di Indonesia, berdasarkan hasil Riset Kesehatan Dasar tahun 2018, prevalensi penyakit muskuloskeletal berdasarkan diagnosis tenaga kesehatan adalah sebesar 7,3\%. Salah satu metode komplementer yang bisa dilakukan untuk mengatasi nyeri LBP adalah dengan melakukan teknik relaksasi otot progresif. Tujuan penelitian ini adalah untuk mengetahui pengaruh relaksasi terapi otot progresif terhadap penurunan skala nyeri LBP. Desain penelitian ini adalah Quasi eksperimental dengan rancangan Pre and Post Test Without Control. Sampel penelitian adalah pengrajin keset di Pos UKK Majun Puskesmas Citangkil sebanyak 30 orang. Hasil analisis univariat diketahui rerata skala nyeri LBP sebelum intervensi relaksasi otot progresif adalah 6,79, sedangkan setelah intervensi relaksasi otot progresif didapatkan rerata skala nyeri LBP 4,03. Dari hasil analisis bivariat diketahui terdapat pengaruh relaksasi otot progresif terhadap skala nyeri LBP pada pengrajin keset di Pos UKK Majun Wilayah Kerja Puskesmas Citangkil Kota Cilegon Tahun 2021 (p value: 0,000). Peneliti menyarankan agar pengrajin mempertahankan metode relaksasi otot progresif jika dikemudian hari mengalami nyeri LBP. Selain itu, untuk pihak manajemen Pos UKK disarankan berkerja sama dengan Puskesmas untuk melakukan pengecekan kesehatan secara berkala dan memberikan edukasi pencegahan nyeri LBP pada para pengrajin.
\end{abstract}

Kata kunci : low back pain, relaksasi otot progresif.

\begin{abstract}
Low Back Pain (LBP) or low back pain is one of the complaints of MSDs (Musculoskeletal Disorders) which is often complained of by tailors. In industrialized countries, about 80 percent of the population has experienced LBP which often occurs at the age of 35 to 55 years. In Indonesia, based on the results of the 2018 Basic Health Research, the prevalence of musculoskeletal disease based on the diagnosis of health workers is $7.3 \%$. One of the complementary methods that can be used to treat LBP pain is to use progressive muscle relaxation techniques. The purpose of this study was to determine the effect of progressive muscle relaxation therapy on reducing the LBP pain scale. The design of this study was a quasi-experimental design with Pre and Post Test Without Control. The research sample was doormat craftsmen at the UKK Majun Post at Citankil Health Center as many as 30 people. The results of the univariate analysis showed that the average LBP pain scale before the progressive muscle relaxation intervention was 6.79 , while after the progressive muscle relaxation intervention the average LBP pain scale was 4.03. From the results of the bivariate analysis, it is known that there is an effect of progressive muscle relaxation on the LBP pain scale in doormat craftsmen at the UKK Majun Post, Citangkil Health Center Work Area, Cilegon City in 2021 (p value: 0.000). Researchers suggest that craftsmen maintain the progressive muscle relaxation method if they experience LBP pain in the future. In addition, for the UKK Pos management, it is recommended to work together with the Puskesmas to carry out regular health checks and provide education on preventing LBP pain to craftsmen.
\end{abstract}

Keywords: low back pain, progressive muscle relaxation

Corresponding author:

Eli Muflihah

eli3007215@gmail.com 


\section{PENDAHULUAN}

Kemajuan teknologi dibidang industri saat ini sudah sangat maju dan banyak hal yang dapat dilakukan dengan serba otomatis, sehingga dapat memberikan kemudahan bagi kehidupan manusia sehari-hari. Namun demikian, penggunaan tenaga manusia secara manual masih belum bisa dihindari secara keseluruhan. Dunia industri di Indonesia, khususnya pada sektor informal masih banyak yang menggunakan tenaga manusia dalam hal penanganan material (Tarwaka, 2014). Salah satu industri disektor informal adalah industri kerajinan. Menurut Tarwaka (2014), industri kerajinan sangat lekat dengan pekerjaan yang menggunakan tenaga manusia, sehingga memiliki potensi bahaya dan risiko, baik yang bersumber dari aktivitas kerja, alat dan bahan yang digunakan, maupun lingkungan.

Menurut WHO (2011) di negara maju kurang lebih 70 sampai 80 persen penduduknya pernah menderita LBP, 15 sampai 45 persen usia dewasa mengalami LBP setiap tahunnya, diantaranya mengalami serangan yang akut hingga membutuhkan perawatan di rumah sakit. Negara-negara industri, sekitar 80 persen penduduknya pernah mengalami LBP yang sering terjadi pada umur 35 sampai 55 tahun. Di Amerika Serikat, prevalensi LBP sebesar 15 sampai 20 persen, dan insidensi baru berdasarkan jumlah yang melakukan pemeriksaan ke dokter sebesar 14,3 persen. Di Indonesia, berdasarkan hasil Riset Kesehatan Dasar tahun 2018, prevalensi penyakit muskuloskeletal berdasarkan diagnosis tenaga kesehatan adalah sebesar 7,3\% (Kemenkes RI, 2018).

Pekerja industri kerajinan memiliki resiko tinggi terhadap gangguan muskuloskeletal. Penelitian Elza (2012) di Sumatera Barat memperlihatkan bahwa berdasarkan penilaian menggunakan metode RULA, pengrajin songket tradisional beresiko tinggi mengalami penyakit akibat ergonomi. Keluhan musculoskeletal tersering adalah nyeri punggung 80 persen, nyeri bahu kanan 74 persen, dan nyeri pinggang 72 persen. Dari hasil tersebut terlihat bahwa keluhan yang paling banyak muncul adalah keluhan pada punggung.

Solehati \& Kosasih (2015) menyatakan bahwa teknik relaksasi otot progresif merupakan sebuah metode yang bisa dilakukan untuk mengatasi intensitas nyeri pada punggung. Teknik Relaksasi otot progresif tidak memiliki efek samping, sangat mudah dilakukan dan salah satu metode relaksasi termurah yang ada saat ini. Teknik relaksasi otot progresif adalah terapi relaksasi dengan gerakan mengencangkan dan melemaskan otototot pada satu waktu untuk memberikan perasaan relaksasi secara fisik.

Dari latar belakang dan permasalahan diatas penulis merasa tertarik untuk melakukan sebuah penelitian dengan judul "Pengaruh relaksasi terapi otot progresif terhadap penurunan skala nyeri low back pain (LBP) pada pengrajin keset di Pos UKK Majun Wilayah Kerja Puskesmas Citangkil Kota Cilegon Tahun 2021”.

\section{METODE PENELITIAN}

Desain yang digunakan pada penelitian ini adalah desain penelitian kuantitatif, dengan rancangan penelitian Quasy Eksperimental dengan Pre and post test without control, yang artinya peneliti hanya melakukan intervensi pada satu kelompok tanpa pembanding. Pengaruh perlakuan dinilai dengan cara membandingkan nilai post test dengan pre test (Dharma, 2015).

Variabel penelitian terdiri dari 2 variabel, yaitu skala nyeri sebelum dan sesudah intervensi relaksasi otot progresif.

Populasi penelitian ini ialah seluruh pekerja konveksi pembuatan keset di Pos Usaha Kesehatan Kerja (UKK) Majun Kecamatan Citangkil Kota Cilegon yang berjumlah 30 orang. Karena jumlah populasi kurang dari 100, maka teknik pengambilan sampel dalam penelitian ini menggunakan teknik total sampling, yaitu dengan mengambil semua anggota populasi dijadikan obyek atau responden penelitian. Jadi jumlah sampel dalam penelitian ini sebanyak 30 responden.

1. Kriteria Inklusi

a. Sedang mengalami nyeri punggung

b. Bisa membaca dan menulis dengan baik

2. Kriteria Eksklusi

a. Tidak berada di tempat saat penelitian

b. Tidak bersedia menjadi responden penelitian

Alat pengumpulan data yang digunakan adalah kuesioner skala nyeri Numeric Rating Scale (Skala Nyeri NRS). Responden hanya 
memilih skala intensitas nyeri yang dirasakan sesuai dengan rentang skala nyeri $0-10$ sebagai berikut :

\begin{tabular}{|l|l|l|l|l|l|l|l|l|l|l|}
\hline 0 & 1 & 2 & 3 & 4 & 5 & 6 & 7 & 8 & 9 & 10 \\
\hline
\end{tabular}

Dalam penelitian ini, intervensi relaksasi otot progresif dilakukan selama 1 minggu berturut-turut. Pelaksanaanya dengan membagi responden menjadi 3 kelompok, jadi masing-masing kelompok berisi 10 orang. Pelaksanaan relaksasi otot progresif dilakukan secara bergantian perkelompok, setelah kelompok 1 selesai lalu istirahat kurang lebih 30 menit kemudian dilanjutkan dengan kelompok 2 dan setelah selesai kembali beristirahat selama 30 menit dan kemudian dilanjut dengan kelompok 3 .

Analisis data yang digunakan adalah analisis univariat, yaitu untuk mengetahui nilai rata-rata skala nyeri sebelum dan sesudah intervensi relaksasi otot progresif. Sedangkan analisis bivariat yang digunakan adalah uji statistik dependent $\mathrm{t}$ test dengan syarat data variabel yang dianalisis berdistribusi normal, atau uji statsistik wilcoxon jika data variabel yang dianalisis berdistribusi tidak normal. Hasil kenormalan data menunjukkan data yang akan dianalisis berdistribusi normal, sehingga dalam penelitian ini analisis bivariat yang digunakan adalah uji statistik dependen $t$ test.

\section{HASIL}

\section{Karakteristik Responden}

Tabel 1

Gambaran Usia Pengrajin Keset di Pos UKK Majun

\begin{tabular}{|c|c|c|}
\hline & & \\
\hline$\geq 35$ Tahun & 20 & 66,7 \\
\hline$<35$ Tahun & 10 & 33,3 \\
\hline Total & 30 & 100,0 \\
\hline
\end{tabular}

Berdasarkan Tabel 1 diketahui bahwa dari 30 pengrajin keset, sebagian besar pengrajin memiliki usia $\geq 35$ tahun sebanyak $20(66,7 \%)$.

Tabel 2

Gambaran Jenis kelamin Pengrajin Keset di Pos UKK Majun

\begin{tabular}{ccc}
\hline Jenis Kelamin & $\mathbf{n}$ & \% \\
\hline Perempuan & 18 & 60,0 \\
Laki-Laki & 12 & 40,0 \\
\hline Total & $\mathbf{3 0}$ & $\mathbf{1 0 0 , 0}$ \\
\hline
\end{tabular}

Berdasarkan Tabel 2 diketahui bahwa dari 30 pengrajin keset, sebagian besar pengrajin berjenis kelamin perempuan sebanyak 18 $(60 \%)$.

\section{Hasil Analisis Univariat \\ Tabel 3}

Rerata Skala Nyeri LBP Sebelum Intervensi Relaksasi Otot Progresif

\begin{tabular}{ccccc}
\hline Variabel & Mean & SD & SE & Min-Max \\
\hline $\begin{array}{c}\text { Skala Nyeri } \\
\text { LBP (Pretest) }\end{array}$ & 6,97 & 0,964 & 0,176 & $5-8$ \\
\hline
\end{tabular}

Berdasarkan Tabel 3 diketahui bahwa rerata skala nyeri LBP sebelum mendapat intervensi relaksasi otot progresif adalah 6,97 dengan standar deviasi 0,964 . Skala nyeri LBP terendah adalah 5 dan skala nyeri LBP tertinggi adalah 8 .

\section{Tabel 4}

Rerata Skala Nyeri LBP Sesudah Intervensi Relaksasi Otot Progresif

\begin{tabular}{ccccc}
\hline Variabel & Mean & SD & SE & $\begin{array}{c}\text { Min- } \\
\text { Max }\end{array}$ \\
\hline $\begin{array}{c}\text { Skala Nyeri } \\
\text { LBP (Postest) }\end{array}$ & 4,03 & 1,671 & 0,305 & $1-7$ \\
\hline
\end{tabular}

Berdasarkan Tabel 4 diketahui bahwa rerata skala nyeri LBP sesudah mendapat intervensi relaksasi otot progresif adalah 4,03 dengan standar deviasi 1,671. Skala nyeri LBP terendah adalah 1 dan skala nyeri LBP tertinggi adalah 7.

\section{Hasil Analisis Bivariat}

Tabel 5

Pengaruh Relaksasi Otot Progresif Terhadap Skala Nyeri LBP

\begin{tabular}{cccccc}
\hline $\begin{array}{c}\text { Skala } \\
\text { Nyeri } \\
\text { LBP }\end{array}$ & Mean & SD & \multicolumn{2}{c}{$\begin{array}{c}\text { Paired } \\
\text { Difference }\end{array}$} & $\begin{array}{c}\text { P } \\
\text { value }\end{array}$ \\
\cline { 1 - 1 } $\begin{array}{c}\text { Sebelum } \\
\text { Intervensi } \\
\text { ROP }\end{array}$ & 6,97 & 0,964 & & & \\
\cline { 1 - 1 } $\begin{array}{c}\text { Sesudah } \\
\text { Intervensi } \\
\text { ROP }\end{array}$ & 4,03 & 1,671 & & & \\
\cline { 1 - 2 } \\
\hline
\end{tabular}
intervensi relaksasi otot progresif adalah 6,97 dengan standar deviasi 0,964, sedangkan setelah mendapat intervensi relaksasi otot progresif didapatkan Rerata skala nyeri LBP sebesar 4,03 dengan standar deviasi 1,671.

Terdapat penurunan Rerata skala nyeri LBP sesudah mendapat intervensi relaksasi otot progresif sebesar 2,933 dengan standar deviasi 
1,337. Hasil uji statistik didapat p value 0,000 , pada alpha 0,05 didapat $\mathrm{p}<$ alpha, maka dapat disimpulkan terdapat pengaruh relaksasi otot progresif terhadap skala nyeri LBP pada pengrajin keset di Pos UKK Majun Wilayah Kerja Puskesmas Citangkil Kota Cilegon Tahun 2021.

\section{PEMBAHASAN}

\section{Gambaran Karakteristik Pengrajin Keset di Pos UKK Majun}

Usia adalah salah satu faktor predisposisi kejadian Low Back Pain (LBP). Bull \& Archard (2014) menyatakan LBP memiliki dua kelompok faktor resiko, salah satunya faktor yang berasal dari diri sendiri atau individu, seperti umur atau degeneratif. Kejadian LBP sering terjadi pada umur 35 tahun dan meningkat pada umur 55 tahun.

Hasil penelitian menggambarkan bahwa mayoritas pengrajin keset di Pos UKK Majun Wilayah Kerja Puskesmas Citangkil Kota Cilegon memiliki usia $\geq 35$ tahun (60\%).

Melihat hasil penelitian dan teori yang ada, bisa dilihat bahwa mayoritas pengrajin keset di Pos UKK Majun Wilayah Kerja Puskesmas Citangkil Kota Cilegon memiliki resiko tinggi mengalami nyeri LBP karena sebagian besar berusia lebih dari 35 tahun. Muttaqin (2012) menyatakan bahwa perubahan degenerasi pada diskus intervetebra akibat bertambahnya umur menjadi fibrokartilago yang padat dan tidak teratur adalah penyebab nyeri punggung biasa, L4 sampai L5 dan L5 sampai S1 mengalami stres mekanis dan menekan sepanjang radiks saraf tersebut. Keluhan nyeri punggung bawah dan terbatasnya aktivitas menyebabkan keluhan pada klien LBP.

Tarwaka (2014) juga menyatakan bahwa LBP memiliki ekaitan erat dengan usia. Keluhan LBP biasanya dirasakan pada usia 35 dan meningkat seiring pertambahan usia. Semakin lanjut usia, kekuatan dan ketahanan otot mengalami penurunan dan potensi terjadi keluhan otot meningkat. Nelwan et al., (2014) dalam penelitiannya tentang hubungan keluhan nyeri punggung dengan umur dan posisi duduk pada sopir angkutan menyebutkan bahwa pada umur 20 sampai 29 tahun kekuatan otot akan menjadi maksimal, selanjutnya akan terjadi penurunan kekuatan otot seiring meningkatnya umur. Pada umur lebih dari 30 tahun terjadi proses degenerasif yang dimulai oleh terjadinya kerusakan jaringan saat penggantian jaringan, menjadi jaringan parut dan cairan berkurang yang membuat stabilitas tulang dan otot jadi berkurang. Dengan bertambahnya umur elastisitas pada tulang belakang juga semakin menurun dan menjadi penyebab terjadinya LBP. Hasil penelitian Fathoni (2009) di RSUD Purbalingga menunjukkan bahwa ada hubungan yang signifikan antara kejadian LBP dengan umur perawat.

Hasil penelitian menggambarkan bahwa mayoritas pengrajin keset di Pos UKK Majun Wilayah Kerja Puskesmas Citangkil Kota Cilegon berjenis kelamin perempuan (60\%). Perempuan dan lakulaki memiliki perbedaan terutama dari segi ketahanan fisik. Secara umum perempuan memiliki ketahanan fisik lebih lemah jika dibanding dengan laki-laki. Tarwaka (2014) menyebutkan bahwa kekuatan fisik tubuh perempauan adalah $2 / 3$ dari laki-laki. Hal tersebut karena secara fisiologis, kemampuan otot perempuan lebih rendah dari laki-laki.

Perbedaan ketahanan fisik tersebut membuat perempuan memiliki resiko lebih besar mengalami nyeri LBP dibandingkan dengan laki-laki. Resiko nyeri LBP pada perempuan juga bertambah besar diakibatkan adanya siklus menstruasi dan menopause yang membuat berkurangnya kepadatan tulang akibat adanya hormon estrogen menurun yang mengakibatkan terjadi penurunan osteoblast dan peningkatan osteoklast yang bisa memungkinkan terjadinya nyeri LBP. Hasil penelitian Pandjukang (2020) di RSUD Prof. Dr. W.Z. Johannes Kupang menyebutkan bahwa perempuan memiliki resiko 4 kali lebih besar mengalami nyeri LBP dibandingkan dengan laki-laki.

Hasil penelitian Ekowati (2018) juga menunjukkan bahwa nyeri LBP lebih banyak dialami responden berjenis kelamin perempuan (56\%) dibandingkan pada responden yang berjenis kelamin laki-laki (44\%). Dalam penelitian tersebut disimpulkan bahwa ada hubungan antara jenis kelamin dengan nyeri LBP. 
2. Rerata Skala Nyeri LBP Sebelum Mendapat Intervensi Relaksasi Otot Progresif Pada Pengrajin Keset di Pos UKK Majun

Nyeri Low Back Pain (LBP) adalah suatu rasa nyeri yang hilang timbul pada pinggang bawah bisa sampai ke tungkai atau kaki akibat mobilitas punggung bawah yang sangat tinggi seperti mengangkat benda, membungkuk, atau mengejan. Hasil analisis nyeri LBP pada pengrajin keset di Pos UKK Majun Wilayah Kerja Puskesmas Citangkil Kota Cilegon diketahui bahwa sebelum mendapat intervensi relaksasi otot progresif Rerata nyeri LBP yang dialami adalah 6,97 dengan skala nyeri LBP terendah adalah 5 dan skala nyeri LBP tertinggi adalah 8 .

Hasil tersebut menunjukkan bahwa skala nyeri LBP yang dialami pengrajin keset di Pos UKK Majun Wilayah Kerja Puskesmas Citangkil Kota Cilegon cukup tinggi. Banyak faktor yang bisa menyebabkan para pengrajin keset mengalami nyeri LBP, diantaranya bisa karena faktor usia, jenis kelamin dan faktor sikap kerja para pengrajin. Jika melihat hasil analisis karakteristik pengrajin berdasarkan usia dan jenis kelamin, maka faktor usia dan jenis kelamin bisa dicurigai menjadi salah satu faktor pemicu kejadian LBP pada para pengrajin keset. Seperti yang telah diketahui bahwa mayoritas pengrajin keset berjenis kelamin perempuan dan memiliki usia lebih dari 35 tahun. Hal tersebut dijelaskan oleh Tarwaka (2014) yang menyatakan secara umum perempuan memiliki ketahanan fisik lebih lemah jika dibanding dengan laki-laki dan biasanya keluhan LBP mulai dirasakan pada usia 35 dan meningkat seiring pertambahan usia. Semakin lanjut usia, kekuatan dan ketahanan otot mengalami penurunan dan potensi terjadi keluhan otot meningkat.

Selain usia dan jenis kelamin, faktor sikap kerja juga bisa dicurigai sebagai salah satu pemicu tingginya nyeri LBP yang dialami para pengrajin keset. Hasil observasi di lapangan saat penelitian didapatkan gambaran bahwa para pengrajin keset bekerja dengan sikap kerja yang kurang baik, seperti sikap kerja yang statis dan desain kursi kerja yang tidak ergonomis. Tarwaka (2014) menyatakan bahwa kondisi sikap kerja yang tidak ergonomis, ditambah sikap kerja statis yang dilakukan berulang-ulang (repetisi) dapat mempengaruhi kondisi tubuh salah satunya akan mengalami keluhan nyeri punggung bawah (LBP).

Hasil penelitian Sutardi (2017) pada perawat IGD RSUP Dr. Cipto Mangunkusuma menunjukkan bahwa salah satu faktor yang meyebabkan LBP adalah faktor ergonomi atau sikap tubuh saat bekerja $(\mathrm{pv}=0,040)$. (Kurnawidjaya, 2014) dalam penelitiannya tentang pengendalian resiko ergonomi kasus LBP juga menjelaskan bahwa pekerja yang berisiko tinggi mengalami LBP adalah pekerja yang bekerja dengan postur janggal, manual handling serta dengan frekuensi dan durasi yang tinggi.

Anies (2014) dalam penelitiannya menyatakan bahwa sikap tubuh dan aktivitas pada alat kerja memiliki potensi resiko menyebabkan gangguan kesehatan atau penyakit. Sikap tubuh yang salah saat bekerja bisa menyebabkan gangguan kesehatan seperti kelelahan, nyeri, dan menyebabkan kecelakaan kerja. Sikap kerja statis baik itu duduk ataupun berdiri jika dilakukan dalam waktu yang relatif lama juga bisa menimbulkan permasalahan kesehatan. Hasil penelitian Wijayanti (2019) pada penjahit konveksi di Kelurahan Way Halim Kota Bandar Lampung menunjukkan bahwa sebanyak 46,5\% penjahit mengeluhkan LBP akibat posisi duduk membungkuk dan akibat lama duduk statis $\geq 4$ jam sebanyak $46,5 \%$. Kesimpulan penelitian tersebut adalah ada hubungan yang bermakna antara lama duduk dan posisi duduk responden terhadap kejadian LBP.

3. Rerata Skala Nyeri LBP Sesudah Mendapat Intervensi Relaksasi Otot Progresif Pada Pengrajin Keset di Pos UKK Majun

Hasil analisis nyeri LBP pada pengrajin keset di Pos UKK Majun Wilayah Kerja Puskesmas Citangkil Kota Cilegon diketahui bahwa sesudah mendapat intervensi relaksasi otot progresif Rerata nyeri LBP yang dialami adalah 4,03 dengan skala nyeri LBP terendah adalah 1 dan 
skala nyeri LBP tertinggi adalah 7. Teknik relaksasi otot progresif adalah terapi relaksasi dengan gerakan mengencangkan dan melemaskan otot-otot pada satu waktu untuk memberikan perasaan relaksasi secara fisik

Solehati \& Kosasih (2015) menyatakan bahwa teknik relaksasi otot progresif merupakan sebuah metode yang bisa dilakukan untuk mengatasi intensitas nyeri pada punggung. Teknik Relaksasi otot progresif tidak memiliki efek samping, sangat mudah dilakukan dan salah satu metode relaksasi termurah yang ada saat ini. Menurut Setyoadi \& Kushariyadi, 2011), relaksasi otot progresif (ROP) adalah terapi komplementer yang bisa diberikan atau diajarkan oleh perawat terhadap klien dengan berbagai gangguan, salah satunya pada klien dengan gangguan nyeri punggung bawah (LBP), ROP bisa memberikan efek perasaan rileks karena bisa melancarkan aliran darah dan menurunkan ketegangan otot.

Prinsip dari ROP adalah membuat otot dan pikiran relaks dengan cara pereganagan dan pengenduran setiap kumpulan otot selama lima detik dan pemusatan pikiran diikuti dengan napas dalam lalu melepaskan ketegangan hingga otot menjadi lemas. Hal tersebut akan menghasilkan relaksasi progresif pada tubuh dan menenangkan pikiran. Setyoadi \& Kushariyadi (2011) menyatakan bahwa ROP adalah teknik relaksasi yang menggabungkan serangkaian seri kontraksi dan relaksasi otot dengan latihan napas dalam.

Lestari \& Yuswiyanti (2014) menjelaskan bahwa ROP bisa memberikan rasa nyaman pada responden disebabkan ROP bisa membuat meningkatnya produksi hormon endorphin dalam darah dan menghambat ujung-ujung saraf nyeri serta mencegah stimulus nyeri masuk dalam medula spinalis, hingga akhirnya di kortek serebri kualitas nyeri diinterpretasikan berkurang.

\section{Pengaruh Relaksasi Otot Progresif Terhadap Skala Nyeri LBP Pada Pengrajin Keset di Pos UKK Majun}

Hasil analisis pengaruh relaksasi otot progresif terhadap skala nyeri pada pengrajin keset di Pos UKK Majun Wilayah Kerja Puskesmas Citangkil Kota Cilegon menunjukkan bahwa Rerata skala nyeri LBP sebelum mendapat intervensi relaksasi otot progresif adalah 6,97, sedangkan setelah mendapat intervensi relaksasi otot progresif didapatkan Rerata skala nyeri LBP menjadi 4,03.

Dari hasil analisis tersebut diketahui ada penurunan Rerata skala nyeri LBP sesudah mendapat intervensi relaksasi otot progresif sebesar 2,933. Hasil uji statistik didapat $\mathrm{p}$ value 0,000 , pada alpha 0,05 didapat $\mathrm{p}<$ alpha, maka dapat disimpulkan terdapat pengaruh relaksasi otot progresif terhadap skala nyeri LBP pada pengrajin keset di Pos UKK Majun Wilayah Kerja Puskesmas Citangkil Kota Cilegon Tahun 2021.

Hasil penelitian ini sesuai dengan teori Solehati \& Kosasih (2015) yang menyatakan bahwa teknik relaksasi otot progresif merupakan teknik relaksasi yang bisa dilakukan untuk mengatasi intensitas nyeri pada punggung dengan cara membuat gerakan-gerakan pengencangan dan pelemasan otot-otot. Soewondo \& Lathifah (2016) menjelaskan bahwa relaksasi progresif adalah keterampilan yang bisa digunakan untuk mengurangi ketegangan dan rasa tidak nyaman yang bisa dilakukan secara mandiri. Lebih lanjut dijelaskan bahwa ketegangan adalah kondisi yang berkaitan dengan serabut otot-otot yang mengecil, untuk menghilangkan ketegangan tersebut diperlukan kontraksi-kontraksi pada otot.

Hasil penelitian ini juga sejalan dengan hasil penelitian Dewi et al. (2018) di Puskesmas Cibeureum Kota Tasikmalaya yang menunjukkan bahwa relaksasi otot progresif bisa menurunkan skala nyeri punggung bagian bawah, Rerata nyeri sebelum intervensi sebesar 4,67 dan setelah intervensi relaksasi otot progresif menurun menjadi 2,30. Hasil uji statistic didapatkan $\mathrm{p}$ value sebesar 0.000 maka disimpulkan bahwa ada pengaruh relaksasi otot progresif terhadap penurunan skala nyeri punggung bagian bawah.

Lestari \& Yuswiyanti (2014) menjelaskan bahwa secara fidioogis relaksasi otot progresif (ROP) bisa memberikan rasa nyaman pada responden 
disebabkan ROP bisa membuat meningkatnya produksi hormon endorphin dalam darah dan menghambat ujung-ujung saraf nyeri serta mencegah stimulus nyeri masuk dalam medula spinalis, sehingga kortek serebri tidak menerima sinyal nyeri yang mengakibatkan intensitas nyeri menjadi berubah atau berkurang.

Berdasarkan hasil penelitian ini, peneliti berpendapat bahwa nyeri LBP pada pengrajin keset dipengaruhi oleh faktor usia, jenis kelamin dan sikap kerja. Adanya perbedaan nyeri yang dirasakan para pengrajin diakibatkan oleh perbedaan arti nyeri yang dirasakan, persepsi nyeri, dan reaksi nyeri yang merupakan respon para pengrajin terhadap nyeri tersebut. Nyeri LBP dapat diatasi dengan melakukan relaksasi otot progresif. Klien yang mendapatkan relaksasi tersebut akan merasa tenang, nyaman, rileks, sehingga secara tidak langsung dapat mengurangi tingkat nyeri yang dirasakan.

\section{KESIMPULAN}

Berdasarkan hasil penelitian terhadap 30 pengrajin keset di Pos UKK Majun Wilayah Kerja Puskesmas Citangkil Kota Cilegon didapatkan kesimpulan bahwa ada pengaruh relaksasi otot progresif terhadap skala nyeri LBP pada pengrajin keset di Pos UKK Majun Wilayah Kerja Puskesmas Citangkil Kota Cilegon Tahun 2021 (p value: 0,000).

Berdasar temuan dalam penelitian ini peneliti menyarankan agar pengrajin mempertahankan metode relaksasi otot progresif jika dikemudian hari mengalami nyeri LBP. Selain itu, untuk pihak manajemen Pos UKK disarankan bekerja sama dengan Puskesmas untuk melakukan pengecekan kesehatan secara berkala dan memberikan edukasi pencegahan nyeri LBP pada para pengrajin.

\section{DAFTAR PUSTAKA}

Anies. (2014). Kedokteran Okupasi BerbagaiPenyakit Akibat Kerja dan Upaya Penanggulangan dari Aspek Kedokteran. Ar-Ruzz Media Group.

Bull, E., \& Archard, G. (2014). Nyeri Punggung. Erlangga.
Dewi, Patimah, \& Khairiyah. (2018). Pengaruh Relaksasi Otot Progresif Terhadap Penurunan Nyeri Punggung Bagian Bawah Ibu Hamil Trimester III. Jurnal Bidan "Midwife Journal," 4, 2.

Dharma. (2015). Metodologi Penelitian: Panduan Melaksanakan dan Menerapkan Hasil Penelitian. Trans Info Media.

Ekowati. (2018). Faktor-faktor yang mempengaruhi kejadian nyeri punggung bawah pada perawat yang bekerja di Ruang Katerisasi Jantung RSUPN Dr. Cipto Mangunkusumo Jakarta. Jurnal Keperawatan Medikal Bedah, 1(1), 1-13.

Elza. (2012). Gambaran Tingkat Risiko dan keluhan Subjektif Musculoskeletal Disorders pada Pengrajin Songket Tradisional Silungkang Sumatera Barat. Jurnal Keselamatan Kerja Universitas Indonesia.

Fathoni, H. (2009). Hubungan Sikap dan Posisi Kerja dengan Low Back Pain pada Perawat RSUD Purbalingga. Jurnal Universitas Jendral Soedirman, 21(1), 111.

ILO. (2017). Perekonomian Informal: Transisi menuju Formalisasi.

Kemenkes RI. (2018). Riset Kesehatan Dasar.

Kurnawidjaya. (2014). Pengendalian Risiko Ergonomi Kasus Low Back Pain pada Perawat di Rumah Sakit. Jurnal Kesehatan Masyarakat, 1, 1-9.

Lestari, \& Yuswiyanti. (2014). Pengaruh Relaksasi Otot Progresif Terhadap Penurunan Tingkat Kecemasan pada pasien Pre Operasi di Ruang Wijaya Kusuma RSUD Dr. R. Soeprapto Cepu. Jurnal Keperawatan Maternitas, 2(7), 26.

Muttaqin, A. (2012). Gangguan Muskuloskeletak. EGC.

Nelwan, C. ., Joseph, W. B. ., \& Kawatu, P. A. . (2014). Hubungan Antara Umur dan Posisi Duduk dengan Keluhan Nyeri Punggung Bawah pada Pengemudi 
Angkutan Kota di Kota Bitung. Jurnal Kesehatan Masyarakat Sam Ratulangi, 1(1), 1-8.

Pandjukang. (2020). Hubungan Usia Dan Jenis Kelamin Pada Penderita Nyeri Punggung Bawah (Low Back Pain) Dengan Komorbid Diabetes Melitusdi RSUD PROF. DR. W. Z. Johannes Kupang. Cendana Medical Jurnal, 19(1), 1-7.

Patrianingrum, \& Surahman. (2015). Prevalensi dan Faktor Risiko Nyeri Punggung Bawah di Lingkungan Kerja Anestesiologi Rumah Sakit Dr. Hasan Sadikin Bandung . Jurnal Anastesi Perioperatif, 3, 47-56.

Setyoadi, \& Kushariyadi. (2011). Terapi Modalitas Keperawatan Pada Klien Psikogeriatrik. Salemba Medika.

Soewondo, \& Lathifah. (2016). Stres, Manajemen Stres, dan Relaksasi Progresif (1st ed.). LPSP3.

Solehati, \& Kosasih. (2015). Konsep dan Aplikasi Relaksasi dalam Keperawatan Maternitas. PT. Refika Aditama.

Sukmawati. (2019). Gambaran Potensi Bahaya pada Home Industry Konveksi Kota Semarang (Studi Kasus di Konveksi Permata, Kalisegoro dan Fanny). In Jurnal Kesehatan Masyarakat Universitas Negeri Semarang. Universitas Negeri Semarang.

Sutardi, D. (2017). Faktor-faktor yang berhubungan dengan kejadian Low Back Pain pada perawat Instalasi Gawat darurat RSUPN Dr. Cipto Mangun Kusumo Jakarta. Jurnal Kesehatan Masyarakat Universitas Muhammadiyah, 12(2), 1-17.

Tanderi. (2017). Hubungan Kemampuan Fungsional dan Derajat Nyeri pada Pasien Low Back Pain Mekanik di Instalasi Rehabilitasi Medik RSUP Dr. Kariadi Semarang. Jurnal Kedokteran Diponegoro, 6, 63-72.

Tarwaka. (2014). Keselamatan dan Kesehatan Kerja: Manajemen dan Implementasi K3 di Tempat Kerja. Harapan Press.
WHO. (2011). Low back pain. Bulletin of the World Health Organization.

Wijayanti. (2019). Kejadian Low Back Pain(LBP) pada Penjahit Konveksi di Kelurahan Way Halim Kota Bandar Lampung. Medula, 8, 2.

Wulandari. (2017). Risk Ergonomi dan Keluhan Muskuloskeletal Disordes Pada Pekerja Jahit (Studi di UD. ILFA JAA Konveksi Banyuwangi-Indonesia). Kesehatan Lingkungan Dan Kesehatan Keselamatan Kerja, 1(4), 119-13. 